Krzysztof Kaucha ${ }^{1}$

Katolicki Uniwersytet Lubelski Jana Pawła II

Wydział Teologii

\title{
Wiarygodność Kościoła w dzisiejszej Polsce
}

Gdyby temat niniejszego artykułu brzmiał „Wiarygodność Kościoła w dzisiejszej Wielkopolsce", to należałoby napisać o bogactwie i zasługach Kościoła tego regionu na przestrzeni jego dziejów, że w jego centrum jest najstarsza diecezja w Polsce, że zrodził wielu świętych i błogosławionych, wsławił się obroną polskości w czasie Kulturkampfu, powstaniami wielkopolskimi, bohaterskim protestem w 1956 roku, że w Poznaniu powstały pierwsze w Polsce grupy Anonimowych Alkoholików, że Kościół w Poznaniu doświadczył silnych wewnętrznych turbulencji na początku XXI wieku i je przetrwał, wziął na siebie trud organizacji VIII Kongresu Teologów Polskich w 2010 roku (jak do tej pory ostatniego)2, wnosi do Kościoła w Polsce wiele spokoju, rozwagi i obecnie daje świadectwo swej tożsamości wyrażane w pięknym haśle „Poznań. Chrystus i my”. Do tego wszystkiego, patrząc z perspektywy KUL i teologii fundamentalnej, koniecznie trzeba by dodać postać ks. prof. Romualda Łukaszyka (1930-1981)³, pracownika Sekcji Teologii Fundamentalnej KUL i „ojca Encyklopedii Katolickiej”, i podziękować Kościołowi w Wielkopolsce za niego oraz wielu innych profesorów KUL.

Jednak temat brzmi inaczej, wskutek czego całościowe jego opracowanie zwłaszcza w ograniczonych ramach artykułu jest praktycznie niemożliwe. Celem będzie więc określenie znaczenia pojęcia „wiarygodność Kościoła w dzisiejszej Polsce" oraz wskazanie podstawowych przejawów tej wiarygodności

${ }^{1}$ Ksiądz dr hab. Krzysztof Kaucha, prof. KUL (ur. 1968) — kształcił się pod okiem ks. prof. dr. hab. Mariana Ruseckiego (1942-2012) w stworzonej przez niego Lubelskiej Szkole Teologii Fundamentalnej. Autor dwóch monografii naukowych (Miłość za miłość. Wiarygodność chrześcijaństwa wedlug Battisty Mondina, Lublin 2000; Wiarygodność Kościoła w kontekście wyzwań wspótczesności europejskiej w świetle nauczania Jana Pawła II, Lublin 2008) i wielu innych publikacji (kkaucha@kul.lublin.pl).

${ }^{2}$ Między sensem a bezsensem ludzkiej egzystencji. Teologiczna odpowiedź na fundamentalne pytania współczesnego człowieka. VIII Kongres Teologów Polskich - Poznań, 13-16 września 2010, red. D. Bryl, B. Kochaniewicz, J. Nawrot, E. Kotkowska, Poznań 2012.

${ }^{3}$ M. Rusecki, Łukaszyk Romuald [w:] Leksykon Teologii Fundamentalnej, red. M. Rusecki i in., Lublin-Kraków 2002, s. 763-764. 
z perspektywy teologicznej, głównie eklezjologii fundamentalnej. Nie chodzi tu zatem o optykę osadzoną w innych perspektywach, np. socjologicznej czy medialnej, które zasadniczo różnią się od teologicznej. Konstruowane, zwłaszcza przez massmedia, narracje o Kościele i jego wiarygodności w dzisiejszej Polsce bywają skrajnie odmienne i często uczestniczą w światopoglądowo-politycznej grze. Dla jednych Kościół jest we wszystkim wiarygodny i doskonały, a dla innych nie ma w nim ani nic wiarygodnego, ani nawet dobrego.

$\mathrm{Na}$ strukturę artykułu składają się trzy punkty i zakończenie. Pierwszy punkt będzie poświęcony teologicznemu rozumieniu wiarygodności Kościoła w Polsce w świetle nowych badań i odkryć, drugi — znakom wiarygodności tego Kościoła w ujęciu ks. Mariana Ruseckiego, trzeci — nowym znakom tej wiarygodności w ujęciu piszącego te słowa.

\section{Nowe „odkrycia” w eklezjologii fundamentalnej i ich zastosowanie w badaniu wiarygodności Kościoła w dzisiejszej Polsce}

Nie trzeba udowadniać, że w twórczości Josepha Ratzingera i nauczaniu Benedykta XVI znajduje się bogactwo nowatorskich i bardzo inspirujących treści teologicznych, w tym z zakresu teologii fundamentalnej i eklezjologii fundamentalnej. Są one w Polsce nadal odkrywane ${ }^{4}$. Według Henryka Seweryniaka Ratzinger jest współczesnym Ojcem Kościoła i jest to określenie słuszne ${ }^{5}$. Ratzinger jest niezależny od szkół i mód teologicznych, szuka istoty i fundamentów wiary oraz Kościoła, przez co wnosi do teologii świeżość i głębię, którą należałoby zastosować także w badaniu wiarygodności Kościoła w dzisiejszej Polsce.

Jednymi z najważniejszych „odkryć" u Ratzingera jest jego metoda koncentrowania się na istocie rzeczy oraz sposób definiowania czy ogólnego rozumienia wiarygodności Kościoła. Podczas gdy w akademickiej teologii katolickiej przez wieki, włącznie ze współczesnością, utarło się łączenie tej wiarygodności ze sferą rozumu i tworzeniem argumentujących wywodów, nierzadko skomplikowanych, Ratzinger przyjmuje bardzo prostą jej definicję nieustannie przewijającą się w jego tekstach i myśleniu o Kościele. Wiarygodność Kościoła to według niego „odpowiadanie woli Pana”, a być wiarygodnym oznacza bycie uczciwym, dobrym, prawdomównym, sprawiedliwym, prostym, pokornym, pomagającym, służebnym itd ${ }^{6}$.

${ }^{4}$ Teologia fundamentalna w twórczości Josepha Ratzingera, red. K. Kaucha, J. Mastej, Lublin 2017.

${ }^{5}$ H. Seweryniak, Teologiczna droga Josepha Ratzingera - papieża i wspótczesnego Ojca Kościoła [w:] Niedźwiedź biskupa Korbiniana. W kręgu myśli teologicznej Benedykta XVI, red. H. Seweryniak, K. Sitkowska, P. Artemiuk, Płock 2011, s. 15-74.

${ }^{6}$ J. Ratzinger, Opera omnia, t. VIII: Kościót - znak wśród narodów. Pisma eklezjologiczne i ekumeniczne, red. K. Góźdź, M. Górecka, tłum. W. Szymona, Lublin 2013, cz. 1, s. 425. Zob. K. Kaucha, Inspiracje twórczości Josepha Ratzingera dla teologii fundamentalnej [w:] Teologia 
Odnosząc to do tematu niniejszego artykułu, trzeba by zastanowić się nade wszystko, czy Kościół w dzisiejszej Polsce po prostu odpowiada woli Pana i czy jest uczciwy, dobry, prawdomówny, sprawiedliwy, prosty, pokorny, pomagający, służebny itd. Pytania te dotyczą Eklezji w Polsce jako całości, a także wszystkich jej stanów, Kościołów lokalnych, wspólnot, ruchów, zrzeszeń katolickich, środowisk i członków. Uczciwe postawienie tych pytań i szukanie na nie odpowiedzi to najważniejsze kroki wiodące nie tylko do rzetelnego określania stanu wiarygodności, lecz może także jej budowania czy nawet odbudowywania. Te kroki istotnie przyczyniłyby się też do ujmowania tożsamości Kościoła w Polsce i wyznaczenia głównych celów jego działalności dziś i w najbliższej przyszłości. Wiarygodny jest także ten, kto wie, kim jest i czego chce dokonywać zgodnie ze swą tożsamością.

W eklezjologii Ratzingera jest rozróżnienie na „Jego [Jezusa Chrystusa K.K.] Kościół” i „nasze Kościoły”, a także dostrzeżenie, że „nasze Kościoły” w przeszłości zawodziły i to nierzadko „w sposób porażający”" . Warto by to przenieść na zagadnienie wiarygodności Eklezji w dzisiejszej Polsce. Nie była ona i nie jest rzeczywistością doskonałą. Nie powinniśmy nie dostrzegać słabości Kościoła w Polsce w przeszłości i obecnie. Ile nowego zapału, istotnego dla wiarygodności, zrodziłoby się, gdyby jasno nazwać te słabości po imieniu. Nie chodzi tu wyłącznie o moralne uchybienia członków Kościoła, lecz także słabości i niedoskonałości struktur, działań pastoralnych czy tzw. mentalności kościelnej. Wielką zasługą Kościoła w naszej Ojczyźnie jest zwycięstwo nad systemem komunistycznym, lecz nie da się zaprzeczyć, że „zainfekował” on wielu członków Kościoła, także duchownych, może nawet nieświadomie z ich strony. Klimat i mentalność współczesności europejskiej, które nastały w Polsce po upadku komunizmu, charakteryzujące się relatywizmem, subiektywizmem i konsumpcjonizmem, dziś ,infekują” wielu członków i wspólnot tego Kościoła.

W tym kontekście trzeba przypomnieć, że to wierni świeccy zainicjowali ekspiacyjną Wielką Pokutę w ramach jubileuszu 1050. rocznicy chrztu Polski, która odbyła się w duchowej stolicy naszej Ojczyzny 15 października 2016 roku. Nic bardziej nie wzmacnia wiarygodności niż uczciwe, pokorne stanięcie przed Bogiem w prawdzie o sobie, zmierzające ku nawróceniu i odnowie. Wiarygodność Kościoła zasadniczo różni się od wiarygodności czy poprawiania wizerunku kogoś lub czegoś w przestrzeni publicznej. W perspektywie teologicznej wiarygodność Kościoła jest budowana przede wszystkim przez Boga i jest odbiciem wiarygodności Jego samego, którą wprawdzie można odrzucić, lecz której nie

fundamentalna w twórczości Josepha Ratzingera, red. K. Kaucha, J. Mastej, Lublin 2017, s. $283-$ 302, tu: s. 294.

7 J. Ratzinger, Opera omnia, t. VIII: Kościót - znak wśród narodów. Pisma eklezjologiczne i ekumeniczne, red. K. Góźdź, M. Górecka, tłum. W. Szymona, Lublin 2013, cz. 2, s. 1084-1098, cytat ze s. 1095 . 
można obalić. Jak określił to Edward Schillebeeckx, można zniszczyć struktury Kościoła, lecz nie można zniszczyć jego samego; od momentu pojawienia się Jezusa Chrystusa, prawdziwego Boga i prawdziwego człowieka, w dziejach świata nie można zniszczyć idei o Nim i Jego wspólnocie z ludźmi jako Jego Ciele. Jakiekolwiek powierzchowne zabiegi „pijarowskie” prędzej czy później wyjdą na jaw ze szkodą dla wiarygodności, natomiast osadzenie jej od początku na prawdzie okazuje się trwałe. Choć Ratzinger rozróżnia „Jego Kościół” i „,nasze Kościoły”, to jednocześnie twierdzi, że te ostatnie czerpią tożsamość z Tego Pierwszego i nieustannie mają szansę odradzać się, odmładzać - w tym też ich wiarygodność — przez ożywianie więzi z Jego Kościołem.

Ważne dla podjętego w artykule tematu odkrycia zawiera także opracowanie Oblicza Kościoła katolickiego w Polsce. 1050. rocznica Chrztu ${ }^{8}$. Wskazuje ono na różne oblicza, które w przeszłości i obecnie ma Eklezja w Polsce, lecz które wynikają z czegoś w stosunku do nich uprzedniego, a mianowicie jej tożsamości, której źródłem jest tożsamość w Bogu. Z teologicznego punktu widzenia wiarygodność Kościoła w dzisiejszej Polsce zakorzeniona jest w wiarygodności Kościoła Powszechnego, a jeszcze głębiej — wiarygodności Jezusa Chrystusa. Wynika z tego też, że najlepszym sposobem budowania czy odnawiania wiarygodności Kościoła jest odnajdywanie swej tożsamości i misji w Bogu.

$\mathrm{Z}$ powyższych racji, patrząc teologicznie, nie jest poprawne stwierdzenie, że Kościół w Polsce ma trochę ponad 1050 lat. Ma on tyle lat, ile ma cały Kościół jako historyczno-społeczne Ciało Pana. Geneza jego sięga nawet „przedczasowości", skoro jest on zawarty w przedwiecznej ekonomii Bożej. Notabene, znów wracając do „odkryć” u Ratzingera, warto zauważyć, że często przypominał on o niefortunnej zamianie znaczeń pojęć Corpus verum i Corpus mysticum, które dokonało się w teologii. Od początków Eklezji do średniowiecza jako Corpus verum rozumiano Kościół, czyli wspólnotę Głowy z członkami Ciała i członków ze sobą, jako Corpus mysticum zaś - Eucharystię. Później nastąpiła zamiana9. Czy w polskich realiach od długiego już czasu nie skutkuje to zjawiskiem tzw. auto-ekskomunikowania się z Kościoła („Kościół to oni”, czyli duchowni)? Co zrobić, by ten stereotyp usuwać i przywracać właściwe myślenie o przynależności i odpowiedzialności za Kościół (w języku Ratzingera: o utożsamianiu się z Kościołem)?

W opracowaniu Oblicza Kościoła katolickiego w Polsce. 1050. rocznica Chrztu wyróżniono zasadnicze wymiary bytu i działalności Kościoła w naszej Ojczyźnie, a także nazwano jego bogactwo wypracowywane przez wieki, które świadczy o jego wiarygodności. To ważne zagadnienie, ponieważ rzetelne mówienie o wiarygodności Kościoła w dzisiejszej Polsce musi objąć jego uwia-

${ }^{8}$ Oblicza Kościoła katolickiego w Polsce. 1050. rocznica Chrztu, red. J. Mastej, K. Kaucha, P. Borto, Lublin 2016.

9 J. Ratzinger, Opera omnia, t. VIII/1, s. 136. Zob. K. Kaucha, Inspiracje ..., s. 292-293. 
rygodnianie się w przeszłości. W Lubelskiej Szkole Teologii Fundamentalnej zwraca się uwagę m.in. na kryteria wiarygodności z próby czasu, pozytywnego bilansu obecności Kościoła w dziejach ${ }^{10}$ oraz argumentów kulturotwórczego ${ }^{11}$ i historiotwórczego.

Autorzy artykułów zamieszczonych we wspomnianej książce wskazali przejawy bogactwa Eklezji w Polsce u jej początków (Krzysztof Ożóg), w kulturze polskiej (Kazimierz Ożóg), świętych i błogosławionych (o. Gabriel Bartoszewski), niezłomności w okresie PRL (Jan Żaryn), sferze społecznej (ks. Janusz Mariański), religijności ludowej (ks. Zdzisław Kupisiński), dziedzinie etyczno-moralnej (ks. Tadeusz Zadykowicz), charytatywnej (s. Małgorzata Chmielewska), ekumenizmu (ks. Marcin Składanowski), w ruchach wiernych świeckich (o. Adam Schulz), działalności misyjnej (ks. Marcin Wrzos) i teologii narodu polskiego (ks. Rafał Pokrywiński ${ }^{12}$ ). Uwyraźnili, że Kościół w Polsce wniósł znaczący wkład do Kościoła powszechnego i skarbca Ojczyzny. Jest łatwo rozpoznawalny w świecie i widziany jako wiarygodny dzięki św. Janowi Pawłowi II, o. Maksymilianowi Kolbe i s. Faustynie Kowalskiej ${ }^{13}$. Powstało w nim wiele pionierskich i wzorcowych dzieł charytatywnych, jak o. Adama Chmielowskiego, Ignacego Kłopotowskiego czy s. Róży Czackiej. Historycy, socjologowie i teologowie zwrócili jednak uwagę, że duże zaangażowanie charytatywne i patriotyczne, także w niedawnych czasach PRL, przejawiała tylko część społeczności Kościoła, czasami „mała trzódka”. Wszystko to pozwala urealnić zasięg i stopień intensywności wiarygodności Eklezji w Polsce dawniej, a także obecnie. Przy dokładniejszym spojrzeniu okazuje się, że Kościół w Polsce jest wewnętrznie różnorodny i obejmuje zróżnicowane kręgi — zróżnicowane pod względem stopnia utożsamiania się z nim i, co za tym idzie, wiarygodności.

${ }^{10} \mathrm{~K}$. Kaucha, Wiarygodność Kościoła $w$ kontekście wyzwań współczesności europejskiej w świetle nauczania Jana Pawła II, Lublin 2008, s. 44-53.

${ }^{11}$ M. Rusecki, Kulturotwórczy argument [w:] Leksykon Teologii Fundamentalnej, red. M. Rusecki i in., Lublin-Kraków 2002, s. 730-742.

12 Oblicza Kościoła katolickiego w Polsce. 1050. rocznica Chrztu, red. J. Mastej, K. Kaucha, P. Borto, Lublin 2016: K. [Krzysztof] Ożóg, Narodziny wiary i Kościoła na ziemiach polskich, s. 13-28; K. [Kazimierz] Ożóg, Kościót jako „,spiritus movens” kultury polskiej, s. 29-40; G. Bartoszewski, Święte oblicze Kościoła w Polsce, s. 41-89; J. Żaryn, Niezłomne oblicze Kościoła katolickiego w czasach PRL, s. 91-101; J. Mariański, Społeczne oblicze Kościoła katolickiego w Polsce, s. 113-138; Z. Kupisiński, Polska religijność ludowa, s. 139-163; T. Zadykowicz, Moralne oblicze Kościoła katolickiego w Polsce, s. 165-183; M. Chmielewska, Charytatywne oblicze Kościoła w Polsce, s. 185-194; M. Składanowski, Ekumeniczne oblicze Kościoła katolickiego w Polsce, s. 195-210; A. Schulz, Ruchy świeckich obliczem Kościoła katolickiego w Polsce, s. 219-233; M. Wrzos, Misyjne oblicze Kościoła katolickiego w Polsce, s. 235-254; R. Pokrywiński, Z teologii narodu polskiego, s. 255-273.

${ }^{13}$ K. Kaucha, Tożsamość Kościoła w Polsce [w:] Oblicza Kościoła katolickiego w Polsce. 1050. rocznica Chrztu, red. J. Mastej, K. Kaucha, P. Borto, Lublin 2016, s. 275-306. 
Bardzo pożyteczne było wysłuchanie głosu cudzoziemców w kwestii wiarygodności Kościoła w Polsce, co uczyniono we wspomnianej książce ${ }^{14}$. Polacy na ogół mało uświadamiają sobie, że świadectwo ich Kościoła w minionych dekadach przyniosło jako skutek nawrócenie wielu i odrodzenie nadziei w naszej części Europy, oraz że Kościół w Polsce jest postrzegany jako żywy, dynamiczny, jako ten, który przechowuje wiarę. Czasami cudzoziemcy zwracają uwagę na niebezpieczeństwo utożsamiania przez Polaków narodu z chrześcijaństwem.

\section{Znaki wiarygodności Kościoła w Polsce w ujęciu księdza Mariana Ruseckiego}

W tym punkcie zostanie omówione znakowe badanie wiarygodności Kościoła w dzisiejszej Polsce. Pionierem tej metody był Marian Rusecki. Po raz pierwszy pisał o niej na początku lat 90 . minionego stulecia ${ }^{15}$. Dokonał wówczas, na początku tzw. okresu transformacji, diagnozy wiarygodności Eklezji w naszej Ojczyźnie. Wskazał 10 znaków wiarygodności i podjął próbę oceny, w jakim stopniu występują. Zostanie tu pominięte ich teologiczne podłoże, choć jest bardzo ważne i decyduje o właściwym ich rozumieniu, natomiast uwaga będzie zogniskowana na zagadnieniu ich realizacji, które ma decydujące znaczenie w kwestii wiarygodności Kościoła w Polsce.

Ksiądz Rusecki wymienił następujące znaki: Piotra, Kolegium Apostolskiego, jedności, świętości, powszechności, apostolskości, agapetologiczny, prakseologiczny, martyriologiczny i kulturotwórczy. Jego zdaniem wiele tych znaków można zaobserwować w Kościele w Polsce, jednakże żaden nie funkcjonuje w stu procentach.

Na przykład znak Piotra, zwłaszcza za pontyfikatu Jana Pawła II, był bardzo wyraźny, jednak posługa następcy Piotra bywała redukowana do sfer politycznej, społecznej i ekonomicznej. Nie przez wszystkich była właściwie rozumiana. Niektórzy katolicy w Polsce nie akceptują nauczania papieża (Kościoła) w kwestii prawa do życia od poczęcia do naturalnej śmierci. Znaki Kolegium Apostolskiego i apostolskości - według ks. Ruseckiego — choć zasadniczo funkcjonują, to również posiadają braki. W zakresie nauczania duchownym i wiernym świeckim zdarza się głoszenie błędów dogmatycznych i nieścisłości teologicznych,

${ }^{14}$ Blaski i cienie Kościoła katolickiego w Polsce. Świadectwa [w:] Oblicza Kościoła katolickiego w Polsce. 1050. rocznica Chrztu, red. J. Mastej, K. Kaucha, P. Borto, Lublin 2016, s. 307-336. Zostały zamieszczone wypowiedzi s. N. Scopelliti z Włoch, V. Maldijewy z Bułgarii, ks. M. Deselaersa z Niemiec i M. Steblera ze Szwajcarii.

${ }^{15}$ M. Rusecki, Czy Kościół w Polsce jest wiarygodny? [w:] Wiarygodność Kościoła wobec przemian w Polsce. Quo vadis Ecclesia Polonorum?, red. M. Rusecki, Pelplin-Lublin 1994, s. $143-156$. 
a także ignorancja religijna i selektywność w przyjmowaniu prawd wiary oraz zasad moralnych. W zakresie funkcji uświęcającej te znaki osłabiane są brakami w należytym przygotowaniu się do sakramentów świętych i niewystarczającą świadomością, do czego one w praktyce zobowiązują. Znak jedności i świętości są zacierane wskutek grzechów dotykających wiernych duchownych i świeckich, chodzi zwłaszcza o pychę, upór, zawziętość, brak pokory i skruchy. Każdy człowiek jest grzeszny. W wypadku członków Kościoła zacieraniem tych znaków wiarygodności jest trwanie $\mathrm{w}$ grzechu. Znak powszechności - w ocenie tego teologa - bywa osłabiany wskutek mentalności konsumpcjonistycznej (dobra materialne wystarczą do realizowania się, dają pełnię szczęścia i sensu życia) i kierowania uwagi na Zachód, czemu towarzyszy zapominanie o braciach i siostrach ze Wschodu oraz Południa.

Intensywność występowania znaku agapetologicznego zależy od stopnia obecności miłości w życiu wspólnoty kościelnej. Próbując dostrzec ten znak w szerokich ramach dziejowych, ks. Rusecki napisał:

Nie ulega wątpliwości, że w historii Kościoła powszechnego i w Polsce jaśniały czyny miłości, wyrażające się choćby w okresie stanu wojennego w trosce o internowanych, poszukiwanych, w trosce o biednych, sieroty, samotne matki; w przebaczeniu naszym największym wrogom narodowym, w przemianie serc wielu Polaków, czego nie da się adekwatnie wyliczyć i wymierzyćc ${ }^{16}$.

Znak prakseologiczny dotyczy konieczności wprowadzania prawd i zasad chrześcijańskiej wiary w codzienne życie. Znak martyriologiczny — według Ruseckiego — jest realizowany w podwójny sposób: przez męczeństwo, czyli oddanie życia za wiarę lub bliźnich, i świadectwo życia (trzeba tu dodać, że w tym znaczeniu ten znak pokrywa się ze znakiem prakseologicznym). Rusecki zwracał uwagę na to, że wielu ludzi w Polsce cechuje wiarygodne świadectwo życia, jednak często jest ono niewidoczne, bo jest „ciche”, natomiast głośne są przykłady antyświadectwa. W przekonaniu tego teologa i myśliciela wyraźny jest w Polsce znak kulturotwórczy, gdyż Kościół skutecznie pełnił i pełni funkcję kształtowania kultury duchowej, materialnej, umysłowej, moralnej, religijnej i społecznej. Był współtwórcą i przekazicielem narodowej tradycji i polskości. „Tego nie można nie dostrzegać, chyba że zła wola stoi na przeszkodzie" — konkludował ks. Rusecki ${ }^{17}$.

Choć od czasu, gdy ten teolog dzięki metodzie znakowej diagnozował wiarygodność Kościoła w Polsce upłynęło prawie 25 lat, to jego ocena jest nadal zasadniczo aktualna. Warto by ją przeprowadzić na nowo, w obecnych realiach, z wykorzystaniem narzędzi w postaci badań socjologicznych i ich teologicznej

\footnotetext{
16 Tamże, s. 153.

17 Tamże, s. 155.
} 
interpretacji. Niektóre zjawiska towarzyszące życiu Kościoła w dzisiejszej Polsce są w badaniach socjologicznych nazwane wprost, a nawet mierzone, inne zaś nie wprost lub w ogóle nieuwzględniane, co wynika z niemożliwości dokładnego zmierzenia np. stopnia utożsamiania się z Kościołem. Wiele daje do myślenia znaczny spadek zaufania Polaków do duchownych i wskazywane przez nich tego powody oraz ogólny obraz Kościoła przebijający się w tych badaniach ${ }^{18}$. W celu utworzenia w miarę całościowego obrazu Eklezji w dzisiejszej Polsce i skali wyzwań, przed którymi ona stoi, należałoby uwzględnić wszystko, co ilustruje kondycję i mentalność współczesnych mieszkańców kraju nad Wisłą. Pokazałoby to, jak dokładnie wygląda grunt, na który trafia dziś w Polsce Ewangelia oraz nauczanie Kościoła o np. świętości ludzkiego życia od poczęcia do naturalnej śmierci, jedności i nierozerwalności małżeństwa itp.

\section{„Nowe” znaki wiarygodności Kościoła w dzisiejszej Polsce}

Piszący te słowa starał się poszerzyć metodę znakową Mariana Ruseckiego, uzupełniając listę znaków wiarygodności Kościoła ${ }^{19}$. Efekty tych prac będą wykorzystane w dalszej części tego punktu. Zostanie w nim wyliczonych kilka „dodanych” znaków i będą one odniesione do Eklezji w Polsce, lecz jedynie sygnalizująco, ze względu na ograniczone ramy artykułu. Głównym celem tego wyliczenia będzie wskazanie wielości obszarów, w których obecność Kościoła powinna być dostrzeżona, a wiarygodność — diagnozowana.

W poprzednich punktach artykułu wspomniano o znakach próby czasu i pozytywnego bilansu obecności Kościoła w dziejach. Te znaki jako kryteria czy wskaźniki wiarygodności nadal „pracują”, co oznacza, że pełniejszy obraz wiarygodności Kościoła w dzisiejszej Polsce będzie możliwy do naszkicowania z perspektywy przyszłości.

Jednak już dziś należy dostrzec i inne znaki. Nie są one w ścisłym sensie nowe. Nowa jest jednak świadomość ich obecności, a nawet konieczności dla uwiarygodniania się Kościoła, także w Polsce.

Bez wątpienia w Kościele w Polsce wyraźnie widoczny jest znak charytatywny, nazywany w literaturze teologicznej także znakiem opcji na rzecz ubogich (ks. Andrzej Pietrzak) ${ }^{20}$ czy mizerykordyjnym. Polacy są wrażliwi na biedę, cier-

18 Zob. np. raport CBOS O problemach Kościoła w Polsce (Warszawa, październik 2013; BS/145/2013). Opracował Krzysztof Pankowski; źródło: http://cbos.pl/SPISKOM.POL/2013/ K_145_13.PDF [17.11.2016]. Por. K. Kaucha, Tożsamość..., s. 303.

${ }_{19}$ K. Kaucha, Znaki wiarygodności Kościoła, „Wrocławski Przegląd Teologiczny” 19 (2011) 1, s. 71-89; tenże, Znakowy charakter Kościoła w relacji do uzasadniania jego wiarygodności [w:] Apologia religii, red. P. Moskal, Lublin 2011, s. 249-273.

${ }^{20}$ A. Pietrzak, Opcja na rzecz ubogich znakiem wiarygodności Kościoła, Pieniężno 2002. 
pienie i choroby bliźnich, chętnie wspierają różne akcje charytatywne, których w Polsce jest bardzo wiele. Jest to owoc wielowiekowego oddziaływania Ewangelii i Kościoła. „Zapisem” tego znaku na kartach współczesnej Polski są dzieła i różne formy pomocy charytatywnej, profesjonalni pracownicy i wolontariusze oraz polepszenie się sytuacji życiowej wielu osób, rodzin i środowisk. Trzeba też zauważyć wychodzenie ludzi Kościoła naprzeciw potrzebom społecznym w postaci krzewienia idei wolontariatu, studiów nad rodziną i pracy socjalnej. W krajach zachodnich i północnych dobrze rozwinięta opieka społeczna jest od dawna standardem. Kościół w Polsce w ramach znaku charytatywnego ma szanse zaznaczać swą wiarygodność także tym, że pomoc bliźnim motywowana wiarą chrześcijańską wykracza poza ramy określone przez granice obowiązków, czasu pracy i finansowej gratyfikacji, obejmuje całego człowieka, wraz z jego życiem duchowym i moralnym, i ma na celu doprowadzić do sytuacji, w której wykluczeni nie tylko wracają do społeczeństwa, lecz je sobą ubogacają, a społeczeństwo traktuje ubogich pośród siebie jako swe bogactwo ${ }^{21}$. Tak realizowana pomoc wskazuje na czynnik nadprzyrodzony jako jej źródło. Znak charytatywny jest osłabiany przez postawy obojętności wobec potrzebujących, lekceważenia, ,programowej” podejrzliwości lub - co najbardziej niszczy ten znak — pogardy. Członkowie Kościoła poddawani są dziś wpływom mentalności indywidualistyczno-konsumpcjonistycznej, materialistycznej i liberalistyczno-kapitalistycznej, dla której ludzie ubodzy i ubóstwo są tematem niewygodnym, drażniącym, dlatego chętnie przemilczanym. Znak mizerykordyjny będzie się wzmacniać, gdy Kościół będzie wychodzić naprzeciw nowym potrzebom i potrzebującym, np. ludziom starszym czy imigrantom.

Ze znakiem charytatywnym są związane znaki staurologiczny i rezurekcyjny, które można ująć pod jedną nazwą znaku paschalnego. Wypływa on z rdzenia tożsamości i wiarygodności chrześcijaństwa ${ }^{22}$. Jest ono religią głoszącą Krzyż, śmierć i Zmartwychwstanie Jezusa Chrystusa, a także żyjącą nimi, żyjącą Paschą Jezusa jako najważniejszym kluczem do zrozumienia całej rzeczywistości i tajemnicy człowieka. J. Ratzinger ujął to głęboko w słowach: ,,pascha przechodzenia od sposobu życia tego świata do życia w nowości Ducha, nadal jest jego [Kościoła - K.K.] żywym, podstawowym prawem: tajemnica wielkanocna jest stałą formą kościelnej egzystencji w tym świecie"23.

Nie jest zadaniem Kościoła wyłącznie w Polsce, by żyć Paschą Jezusa nie tylko w okresach wielkiego postu i wielkanocnym. Wprowadzanie lub, inaczej mówiąc, inkulturacja Paschy Jezusa do całego życia Kościoła jest znakiem jego wiarygodności. Nawet jeśli znak charytatywny funkcjonowałby w Kościele w stu procentach, to każdy człowiek — nawet najbogatszy i najzdrowszy — w końcu

${ }^{21}$ Zob. liczne publikacje ks. Wiesława Przygody z KUL.

22 J. Mastej, Staurologiczno-rezurekcyjna wiarygodność chrześcijaństwa, Lublin 2009, $2014^{2}$.

23 J. Ratzinger, Opera omnia, t. VIII/1, s. 423. 
musi zderzyć się z barierą śmierci. W sytuacji kulturowego i religijnego relatywizmu oraz sceptycyzmu wobec religii Kościół, głosząc Paschę Jezusa i żyjąc paschalnie, nie tylko ma szansę zyskać nowych członków i wiarygodność, lecz przede wszystkim dać ocalenie współczesnym ludziom, którzy są zagubieni i poszukują trwałego fundamentu życia. Chodzi zatem o podnoszenie w Kościele świadomości obecności Krzyża w ludzkim życiu oraz podejmowania go z Panem i bliźnimi. Niewłaściwe jest tłumaczenie trudów życia złym losem, grzechami poprzednich pokoleń, działaniem szatana czy Bożą karą. W tym znaku chodzi też o odnoszenie życia ostatecznie do Paschy Pana, a nie praw dziejowych, społecznych, psychologicznych czy neurobiologicznych lub, co gorsza, losu zapisanego w gwiazdach. Tylko Pascha Jezusa daje nadzieję na przekroczenie wszystkich granic, także tej ostatniej, jaką wydaje się śmierć. Kościół w Polsce m.in. dzięki katechezie prowadzonej w szkołach, która obejmuje nadal bardzo dużą liczbę młodzieży, ma ogromną szansę przekazywania istoty chrześcijaństwa i ludzkiego życia zawartej w Passze oraz antropologii paschalnej ${ }^{24}$. Kult i praktyki religijne w Kościele, by zachowały dynamizm, sens i trwałość, muszą ogniskować się na Krzyżu i Zmartwychwstaniu.

Ze znakami staurologicznym i rezurekcyjnym ściśle związane są znaki antropologiczno-wokatywny, sensotwórczy, sperancyjny i eudajmologiczny. Znakiem rozpoznawczym Kościoła i jego wiarygodności jest to, że zna on pełną prawdę o człowieku, która obejmuje także element powołania, Bożego wezwania do bycia coraz bardziej sobą (Jan Paweł II, J. Ratzinger) ${ }^{25}$. Tylko antropologia chrześcijańska nadaje ludzkiemu życiu całościowy sens, jest źródłem trwałej nadziei i doświadczania szczęścia, czyli spełniania siebie, realizowania siebie i kształtowania prawdziwego ,ja". Ta antropologia jest osobotwórcza zarówno w perspektywie indywidualnej, jak i społecznej, które są zresztą w tej antropologii ściśle zespolone. Dlatego chrześcijańska wizja człowieka jest też ze swej natury wspólnototwórcza (komuniotwórcza, communio personarum) i ta jej właściwość jest weryfikacją jej wiarygodności i pożyteczności społecznej. Wydaje się, że ten znak wiarygodności Eklezji w Polsce wyraźnie „błyszczał” w minionych dekadach, gdy liczba seminarzystów i kandydatów do życia konsekrowanego, a konsekwentnie młodych księży i osób konsekrowanych, była w naszym kraju bardzo duża. Możemy to zrewidować dziś, gdy ta liczba w ostatnim czasie gwałtownie spadła. Oczywiście realizować siebie można w kapłaństwie, życiu konsekrowanym, małżeństwie i innych powołaniach. Wzrost liczby rozwodów w Polsce i tzw. związków nieformalnych oraz spadek liczby seminarzystów łączy jakieś logiczne powiązanie, łączące się zarówno $\mathrm{z}$ antropologicznym znakiem

${ }^{24}$ Taką antropologię (homo paschalis) szkicował M. Rusecki w: Pan zmartwychwstat i żyje. Zarys teologii rezurekcyjnej, Warszawa 2006, s. 235-244.

${ }^{25}$ T. Kostecki, Kościót droga życia każdego człowieka. Antropologiczna wiarygodność Kościoła i jej uzasadnianie w świetle nauczania Jana Pawła II, Międzyrzec Podlaski 2015. 
wiarygodności Kościoła, jak i współczesnym kryzysem tożsamości człowieka, który przez nikogo - z wyjątkiem Eklezji - i do niczego nie jest powoływany. Zdaje się, że ten znak w obecnych czasach nie będzie tak spektakularny jak jeszcze niedawno, że będzie „cichy”, co nie znaczy, że mniej prawdziwy czy ważny. Będzie widoczny w indywidualnych zmaganiach o odnalezienie swego powołania i wierność mu, w zmaganiach o sens życia i trwałe szczęście. Wspomóc ten znak może to, że w tzw. osobach powołanych w Kościele widać, że są spełnione, szczęśliwe, że „zapalają” innych.

Z opisanymi powyżej kwestiami związany jest znak wolności i znak wyzwalania, uzdrowienia. Chrześcijaństwo jest $\mathrm{w}$ swej istocie religią wolności i wyzwalania, które z tego tytułu są znakami wiarygodności Eklezji. Chodzi najpierw o wolność w najgłębszym sensie, a mianowicie teologicznym. Według J. Ratzingera ,[w] Kościele chodzi o wolność w najgłębszym sensie tego słowa, o możność uczestnictwa w bycie Bożym"26. Chrzest uwalnia dziecko od grzechu pierworodnego, a dorosłych również od grzechów uczynkowych. Sakrament Pokuty i Pojednania jest także sakramentem wolności i wyzwalania. Nie chodzi tu, jak widać, w pierwszym rzędzie o wolność polityczną czy społeczną, to jednak one są w wolności chrześcijańskiej „założone”. Kościół w Polsce zawsze, także w okresie komunizmu, uwiarygodniał się przez wspieranie dążeń wolnościowych i niepodległościowych, lecz jeszcze mocniej uwiarygodniał się tym, że przyczynił się do rewolucji sumień bez rozlewu krwi. Nawet słuszne dążenie do wolności ma bowiem swoje granice.

W wolnej Ojczyźnie nie znikła potrzeba wolności i wyzwalania. Pojawiły się nowe jej zagrożenia i nowe uzależnienia (od hazardu, pornografii, środków farmakologicznych, przeciwbólowych, urządzeń elektronicznych, mediów społecznościowych) obok starych, nadal funkcjonujących (alkoholizm, nikotynizm, narkomania, pracoholizm). Uzależnienia są w dużej mierze „odpowiedzialne” za depresje i wycofanie się ze społeczeństwa, które z ich powodu ponosi realne straty na wielu płaszczyznach. Mechanizm działania wszystkich uzależnień jest podobny, a co za tym idzie - metody pomocy osobom dotkniętym nimi są też podobne. Uzależnienia nie znają żadnych granic, np. religijnych, społecznych, majątkowych itp. Istotą leczenia uzależnień jest przekonanie uzależnionych, że mogą być wolni, jeśli nie będą sięgać po to, od czego są uzależnieni. Terapie mają na celu wspieranie ich, by trwali w nowym, abstynenckim sposobie życia. Można zatem mówić, że w Polsce dziś zachodzi coraz większa potrzeba pomocy psychologiczno-terapeutycznej osobom cierpiącym, a tym samym zarysowuje się nowy znak wolnościowej wiarygodności Kościoła. Wprawdzie Kościół nie jest w pierwszym rzędzie odpowiedzialny za organizowanie profesjonalnej pomocy w tym zakresie, to jednak podejmuje stosowne inicjatywy. Kościół może mieć

\footnotetext{
${ }^{26}$ J. Ratzinger, Opera omnia, t. VIII/1, s. 408.
} 
istotny wpływ na zmianę stosunku społeczeństwa do osób uzależnionych, w tym kierunku powinien działać i w tym uwidoczniłaby się jego wiarygodność. Ważne jest, by zmieniała się świadomość przede wszystkim duszpasterzy. Mając podstawową wiedzę o uzależnieniach, będą mogli nie tylko kierować cierpiących po właściwą pomoc, lecz także skutecznie wspierać ich zwykłymi środkami łaski, które Kościół ma, a które są też środkami wolności i wyzwalania.

W tym kontekście, a także w kontekście powszechnego dziś w Polsce utożsamiania Kościoła z instytucją, należy dowartościować znak priorytetu Ducha i życia duchowego w Kościele. Nie jest on oczywiście nowy, jednak pojawiły się nowe oznaki zapotrzebowania na niego, a także nowe formy jego realizacji. Kościół w Polsce od dawna cieszy się bogactwem ruchów i wspólnot religijnych, inicjowanych przez Ducha Świętego ożywiającego Eklezję. Są to zarówno ruchy o proweniencji zagranicznej, jak i rodzimej. Ruch Światło-Życie, założony przez ks. Franciszka Blachnickiego, wykazał się pochodzeniem od Ducha dzięki owocom, które przyniósł i przynosi. Kościół w Polsce obejmuje bardzo wiele parafii, które są wspólnotami, ,rodzinami parafialnymi”. W dużych miastach, w których poziom anonimowości jest większy, istnieje zapotrzebowanie na bliższe, wspólnotowe formy życia religijnego proponujące zdrową duchowość i formację. Nie można pominąć faktu, że na Zachodzie odnotowuje się u osób deklarujących się jako niereligijne zjawisko poszukiwania życia duchowego, medytowania, kontaktu z Transcendencją. Wszystko, co tu wcześniej powiedziano, jest dobrym gruntem dla Kościoła w Polsce, by wykazywał się znakiem priorytetu Ducha i życia duchowego. W tym celu potrzebne jest, by jego „liderzy”, duchowni i świeccy, byli ludźmi Ducha i z Ducha, by sami prowadzili życie duchowe, i by dzięki temu byli w tej dziedzinie przewodnikami. Czasami polscy księża mający kontakt z Kościołem w krajach zachodnich zauważają, że podczas gdy u nas dominuje duszpasterstwo akcyjne, tam — długofalowe, formacyjne, oferujące pomoc w kształtowaniu życia duchowego.

Kościół zawsze funkcjonuje w określonej rzeczywistości politycznej i społecznej. Znakiem jego wiarygodności jest zarówno zaangażowanie jego członków w życie polityczne, jak i niezależność od nacisków politycznych. W tej materii Kościół w Polsce zdobył bogate doświadczenie i wiarygodność w okresie komunizmu. Ma liczne powody do dumy, których symbolem jest niezłomny Prymas Stefan Wyszyński. Jednak sytuacja polityczna w Polsce dziś jest inna. W żaden sposób nie zmienia to oczekiwań względem Kościoła: jego członkowie powinni angażować się w życie polityczne przy jednoczesnej odporności na chęć podporządkowania sobie Kościoła przez polityków. Są to rysy wiarygodności Eklezji. Wspólnota Kościoła w Polsce zbiera w tej materii nowe doświadczenia. Nie można ukrywać, że brutalna walka polityczna, w której uczestniczą osoby deklarujące się jako katolicy, jest odbierana jako zgorszenie. To może zrażać do polityki i Kościoła. W tym kontekście można mówić o znakach paksystycznym 
i rekoncyliacyjnym wiarygodności Eklezji w naszej Ojczyźnie, bowiem jest w niej zapotrzebowanie na głos zdrowego rozsądku przypominający o priorytecie pokoju społecznego i współdziałania dla dobra wspólnego. Nie wydaje się możliwe, by udało się zakończyć w Polsce wszystkie spory polityczne lub nawet je istotnie złagodzić, tym bardziej że niektóre środowiska reagują alergiczną nienawiścią na jakiekolwiek wypowiedzi ludzi Kościoła, nawet na tematy mało związane z bieżącą polityką. Patrząc realistycznie, znakiem wiarygodności ludzi Kościoła w Polsce byłaby sytuacja, w której jego członkowie zaangażowani w politykę umieliby zachować godne katolika standardy moralne płynące z wiary i potrafiliby zgodnie współpracować ponad politycznymi podziałami.

Kwestie wyżej poruszone prowadzą do kolejnego znaku wiarygodności Kościoła określanego mianem znaku sprzeciwu (słynne hasło Non possumus), odwagi czy znaku profetycznego. Kościół musi być solą ziemi. Sól w języku biblijnym (Jezusa) jest symbolem prawdy, wierności i wiarygodności. „Jeśli sól utraci swój smak, czymże ją posolić? Na nic się już nie przyda, chyba na wyrzucenie i podeptanie przez ludzi” (Mt 5,13). Odwaga Kościoła do jasnego sprzeciwiania się złu w różnych jego formach, głoszenie konieczności nawrócenia i mówienie prawdy w sytuacji, gdy nie chce się jej usłyszeć, płynie od Boga, jest realizowaniem misji prorockiej i znakiem wiarygodności. Nie chodzi o potępianie ludzi czy świata, lecz zła. Chodzi też o odwagę czynienia moralnej diagnozy zgodnie z prawdą i dla prawdy, dlatego wspomniany znak jest ściśle związany ze znakiem werytatywnym i wolnościowym („Poznacie prawdę, a prawda was wyzwoli”; J 8,32). Jeśli po okresie transformacji w Polsce wahadło troski Kościoła przechylało się w stronę dialogu, tolerancji i otwartości, to obecnie istnieje wyraźna potrzeba mówienia o prawdzie i konieczności nawrócenia (metanoia).

$\mathrm{Na}$ koniec tego punktu warto wspomnieć o znaku czystości wiary, harmonii (koherencji) wiary i rozumu czy podnoszenia wiedzy religijnej. W katolickiej Polsce można zaobserwować bowiem paradoks. $Z$ jednej strony jest dużo wydziałów, instytutów teologicznych i innych nauk kościelnych, wielu pracowników naukowych, w tym teologów, są niespotykane w innych krajach możliwości szerokiej edukacji religijnej, a jednocześnie w polskim społeczeństwie jest dużo ignorancji $\mathrm{w}$ tej dziedzinie. Zbyt często uważa się, że mało ważne jest, w co się wierzy i jak myśli, gdyż najważniejsza jest sama wiara jako posłuszeństwo i zaufanie Bogu oraz praktyki religijne. Świeccy katecheci zwracają uwagę na to, że młodzież przed bierzmowaniem muszą przygotowywać do egzaminu przy pomocy starych książeczek, które są skoncentrowane na głównych prawdach wiary ułożonych pod koniec XVI wieku. Mówią one, że Bóg jest Sędzią sprawiedliwym, który za dobro wynagradza, a za zło karze, natomiast nie mówią o Bożym miłosierdziu, co w Ojczyźnie s. Faustyny jest bardzo dziwne. To tylko jeden z przykładów. Trudno jest z całą stanowczością potwierdzić lub zaprzeczyć, że Polacy jako Słowianie nie cenią zbytnio intelektu, bo bliższe są im racje serca. 
Przeczyłyby temu osiągnięcia intelektualne i naukowe w przeszłości i obecnie. Niemniej istnieje potrzeba, by Kościół w Polsce wykazywał się wspomnianym znakiem uwiarygadniającym.

Wymienione w tym punkcie znaki wiarygodności Eklezji to tylko mała część całości. Obszarów obecności i działalności Kościoła w Polsce, w których widoczna jest także jego wiarygodność oraz jej niedomagania, jest o wiele więcej. Płynący czas i wszelkie przemiany w naszym kraju będą przynosić ze sobą nowe wyzwania stanowiące podłoże do zarówno pojawiania się nowych znaków wiarygodności, jak i ugruntowywania się już obecnych.

\section{Zakończenie}

Posoborowa eklezjologia fundamentalna wypracowała nowe rozumienie Kościoła oraz m.in. jego genezy, natury, istoty i struktur. Wiele uczyniła też w zakresie rozumienia jego wiarygodności i argumentacji na jej rzecz. Teologicznie ujęte pojęcie wiarygodności Kościoła znacząco różni się od ujęć pozateologicznych (czysto historycznych, socjologicznych, politycznych, w mediach). Jego podstawowym źródłem jest Objawienie Boże dokonane w Jezusie Chrystusie i objawiona tożsamość Kościoła mająca źródło w Trójjedynym Bogu. Wśród rozmaitych wysuwanych w tej materii propozycji i koncepcji wyróżnia się wspomniana myśl Josepha Ratzingera: wiarygodność Kościoła oznacza przede wszystkim jego odpowiadanie woli Pana oraz bycie uczciwym, prawdomównym, sprawiedliwym, prostym, dobrym, pokornym, pomagającym i służebnym.

Można zauważyć, przynajmniej w Polsce, że dokonania posoborowej eklezjologii fundamentalnej, dotyczące Kościoła powszechnego, zaczęto „przekładać" na Kościoły w konkretnych krajach i regionach. Służy to z jednej strony ukonkretnianiu znaczenia pojęcia „wiarygodność Kościoła”, a z drugiej — diagnozowaniu faktycznego stanu jego wiarygodności „tu i teraz”. W niniejszym artykule wyróżniono metodę znaków wiarygodności Kościoła, którą ponad 25 lat temu zaczął stosować Marian Rusecki. Przypomniano rezultaty jego prac oraz starano się rozbudować tę metodę. Nie znaczy to, że jest to jedyna droga analizy wiarygodności Eklezji. Jednak ta wydaje się w obecnym czasie najlepsza. Ma gruntowną podbudowę teologiczną, odpowiada teologicznemu posoborowemu rozumieniu Kościoła, jest uniwersalna (może być stosowana do Kościoła w każdym regionie, a także do Kościoła w przeszłości i obecnie) oraz otwarta na wszelkie przemiany i nowe wyzwania, które staną przed Kościołem i będą próbą jego wiarygodności. M. Rusecki zwracał szczególną uwagę na uczciwość i rzetelność diagnozy znaków wiarygodności Eklezji w Polsce, która wymaga też — jego zdaniem - długiej perspektywy czasowej. Do jego uwag trzeba dodać i to, że po analizie poszczególnych znaków należy je potem złożyć w całość, by powstał 
w miarę kompletny obraz wiarygodności Kościoła. Na tej podstawie można wysuwać argumentację uwierzytelniającą na wzór argumentu z konwergencji, za którego twórcę uznaje się Johna Henry’ego Newmana, a który to argument został przypomniany w naszych czasach przez księdza Ruseckiego ${ }^{27}$.

\section{The Credibility of the Church in Contemporary Poland}

\section{Summary}

There are two purposes of this article: the first one - to clarify the meaning of the term 'credibility of the Church in contemporary Poland' from a theological perspective, and the second one - to describe the basic signs of such credibility and the difficulties they are facing. The article consists of three parts and a conclusion. The first part deals with the theological understanding of the Church's credibility in contemporary Poland in the light of new researches and inspirations offered by Joseph Ratzinger's ecclesiology and by the book Oblicza Kościoła katolickiego w Polsce. 1050. rocznica Chrztu [Features of the Catholic Church in Poland. The $1050^{\text {th }}$ Anniversary of the Christening] (ed. by J. Mastej, K. Kaucha, P. Borto, Lublin 2016). The second part is focused on the signs of the Church's credibility in Poland (sign of Peter, of the Apostolic Collegium, of unity, of holiness, of universality, of apostolicity, agapetological, praxeological, martyriological, and culture-creative), which started to be described about 25 years ago by Rev. Marian Rusecki, who was co-founder and the most excellent representative of the Lublin School of Fundamental Theology. The third part presents some new signs of the Church's credibility in Poland according to the author of the article (charitable, staurological, resurrectional, paschal, anthropological-vocational, of freedom, of the priority of the Spirit and spiritual life, of peace and reconciliation, of protest, of the faith's pureness). In the conclusion the author underlines the values of the semeiological method in describing and testing the credibility of the Church in contemporary Poland.

\section{Keywords}

Church, Church in Poland, credibility of the Church, fundamental ecclesiology, fundamental theology, Marian Rusecki, signs of the Church's credibility

\section{Słowa kluczowe}

Kościół, Kościół w Polsce, wiarygodność Kościoła, eklezjologia fundamentalna, teologia fundamentalna, Marian Rusecki, znaki wiarygodności Kościoła

\section{Bibliografia}

Blaski i cienie Kościoła katolickiego w Polsce. Świadectwa [w:] Oblicza Kościoła katolickiego w Polsce. 1050. rocznica Chrztu, red. J. Mastej, K. Kaucha, P. Borto, Lublin 2016, s. 307-336.

Kaucha K., Inspiracje twórczości Josepha Ratzingera dla teologii fundamentalnej [w:] Teologia fundamentalna w twórczości Josepha Ratzingera, red. K. Kaucha, J. Mastej, Lublin 2017, s. $283-302$.

${ }^{27}$ M. Rusecki, Konwergencji argument [w:] Leksykon Teologii Fundamentalnej, red. M. Rusecki i in., Lublin-Kraków 2002, s. 647-648. 
Kaucha K., Tożsamość Kościoła w Polsce [w:] Oblicza Kościoła katolickiego w Polsce. 1050. rocznica Chrztu, red. J. Mastej, K. Kaucha, P. Borto, Lublin 2016, s. 275-306.

Kaucha K., Wiarygodność Kościoła w kontekście wyzwań współczesności europejskiej w świetle nauczania Jana Pawła II, Lublin 2008.

Kaucha K., Znaki wiarygodności Kościoła, „Wrocławski Przegląd Teologiczny” 19 (2011) 1, s. 71-89.

Kaucha K., Znakowy charakter Kościoła w relacji do uzasadniania jego wiarygodności [w:] Apologia religii, red. P. Moskal, Lublin 2011, s. 249-273.

Kostecki T., Kościót droga życia każdego człowieka. Antropologiczna wiarygodność Kościoła i jej uzasadnianie w świetle nauczania Jana Pawła II, Międzyrzec Podlaski 2015.

Leksykon Teologii Fundamentalnej, red. M. Rusecki, K. Kaucha, I.S. Ledwoń, J. Mastej, LublinKraków 2002.

Mastej J., Staurologiczno-rezurekcyjna wiarygodność chrześcijaństwa, Lublin 2009, 2014².

Między sensem a bezsensem ludzkiej egzystencji. Teologiczna odpowiedź na fundamentalne pytania współczesnego człowieka. VIII Kongres Teologów Polskich - Poznań, 13-16 września 2010, red. D. Bryl, B. Kochaniewicz, J. Nawrot, E. Kotkowska, Poznań 2012.

Oblicza Kościoła katolickiego w Polsce. 1050. rocznica Chrztu, red. J. Mastej, K. Kaucha, P. Borto, Lublin 2016.

O problemach Kościoła w Polsce, Komunikat z badań CBOS, Warszawa, październik 2013, BS/145/2013, oprac. K. Pankowski, [online] http://cbos.pl/SPISKOM.POL/2013/K_145_13. PDF [17.11.2016].

Pietrzak A., Opcja na rzecz ubogich znakiem wiarygodności Kościoła, Pieniężno 2002.

Ratzinger J., Opera omnia, t. VIII: Kościót - znak wśród narodów. Pisma eklezjologiczne i ekumeniczne, red. K. Góźdź, M. Górecka, tłum. W. Szymona, część 1 i 2, Lublin 2013.

Rusecki M., Czy Kościót w Polsce jest wiarygodny? [w:] Wiarygodność Kościoła wobec przemian w Polsce. Quo vadis Ecclesia Polonorum?, red. M. Rusecki, Pelplin-Lublin 1994.

Rusecki M., Pan zmartwychwstat $i$ zyje. Zarys teologii rezurekcyjnej, Warszawa 2006.

Seweryniak H., Teologiczna droga Josepha Ratzingera - papieża i wspótczesnego Ojca Kościoła [w:] Niedźwiedź biskupa Korbiniana. W kręgu myśli teologicznej Benedykta XVI, red. H. Seweryniak, K. Sitkowska, P. Artemiuk, Płock 2011, s. 15-74.

Teologia fundamentalna w twórczości Josepha Ratzingera, red. K. Kaucha, J. Mastej, Lublin 2017. 